Volume 3 Issue 1 (2019) Pages 18 - 29

Jurnal Obsesi : Jurnal Pendidikan Anak Usia Dini

DOI: $10.31004 /$ obsesi.v3i1.136

\title{
Pengaruh Model Pembelajaran dan Kemampuan Berpikir Kritis terhadap Pemahaman Sains Fisik
}

\author{
Ayu Citra Dewi ${ }^{1 凶}$ Hapidin $^{2}$, Zarina Akbar ${ }^{3}$ \\ Pascasarjana Pendidikan Anak Usia Dini Universitas Negeri Jakarta
}

\begin{abstract}
Abstrak
Penelitian ini bertujuan untuk mengetahui pengaruh model pembelajaran dan kemampuan berpikir kritis terhadap pemahaman sains fisika pada kelompok B usia 5-6 tahun. Metode penelitian ini adalah eksperimen dengan desain treatment by level $2 \times 2$. Sampel penelitian ini terdiri dari 56 anak. Pengumpulan sampel menggunakan teknik stratified multistage cluster random sampling. Teknik analisis data adalah analisis varians dua jalur (ANAVA). Untuk menguji normalitas data menggunakan uji liliefors dan uji homogenitas menggunakan uji barlett. Hasil penelitian ini menunjukkan bahwa 1) Pemahaman sains fisika anak yang diajar dengan model pembelajaran quantum lebih tinggi daripada model pembelajaran contextual teaching and learning. 2) Terdapat pengaruh interaksi antara model pembelajaran dan kemampuan berpikir kritis terhadap pemahaman sains fisika. 3) Pemahaman sains fisika anak yang diajar dengan model pembelajaran quantum lebih tinggi daripada model pembelajaran contextual teaching and learning pada anak yang memiliki kemampuan berpikir kritis tinggi. 4) Pemahaman sains fisika anak yang diajar dengan model pembelajaran quantum lebih rendah daripada model pembelajaran contextual teaching and learning pada anak yang memiliki kemampuan berpikir kritis rendah.
\end{abstract}

Kata Kunci: model pembelajaran, berpikir kritis, pemahaman sains fisika

\begin{abstract}
The purpose of this study is to know the effect of learning models and critical thinking skills on the understanding of physical science in group B aged 5-6 years. This research method is an experiment with $2 \times 2$ treatment by level design. The study sample consisted of 56 children. Collecting samples use the stratified multistage cluster random sampling technique. The data analysis technique was the analysis of two-way variance (ANAVA). To test the normality of the data using the liliefors test and homogeneity test using the barlett test. The results of this study indicate that 1) Understanding of children's physical science taught by quantum learning models is higher than the learning model of contextual teaching and learning. 2) There is an influence of the interaction between learning models and critical thinking skills on understanding physical science. 3) Understanding of children's physical science taught by quantum learning models is higher than the learning model of contextual teaching and learning in children who have high critical thinking skills. 4) Understanding of children's physical science taught by quantum learning models is lower than the learning model of contextual teaching and learning in children who have low critical thinking skills.
\end{abstract}

Keywords: learning model, critical thinking, understanding of physical science

@ Jurnal Obsesi Prodi PG-PAUD FIP UPTT 2019

$\triangle$ Corresponding author :

Address : Jln. Pemuda I Rawamangun Jakarta Timur ISSN 2356-1327 (Media Cetak)

Email : ayucitar94dewi@gmail.com

ISSN 2549-8959 (Media Online) 


\section{PENDAHULUAN}

Sumber daya manusia yang berkualitas dapat disiapkan dari pendidikan sejak usia dini. Salah satu konten pada pendidikan anak usia dini yang perlu dikembangkan adalah aspek kognitif. Aspek kogintif terdiri dari dua bagian yaitu matematika dan sains.

Sains merupakan salah satu aspek yang penting untuk dipelajari anak usia dini. Pengenalan sains sejak dini bertujuan mengoptimalkan potensi otak anak yaitu dengan melatih kemampuan berfikir ilmiah dan melakukan penyelidikan ilmiah terhadap benda-benda hidup dan tak hidup yang ada di lingkungan sekitar anak. Salah satu ruang lingkup sains menurut National Science Education Standards adalah sains fisika atau (physical science).

Physical science atau sains fisika adalah ilmu yang mempelajari tentang benda tak hidup yang ada di alam semesta, terkait dengan materi fisika dan kimia seperti sifat materi, keadaan materi, perubahan dan perpaduan materi, klasifikasi benda (benda padat, cair dan gas) dan bahan, keseimbangan, berat, energi, pergerakan benda, panas, cahaya dan suara.(Olcer, 2017). Kemiss dan DeVries dalam penelitian Kato and Van Meeteren menyatakan sains fisika atau physical science merupakan aktivitas anakanak melakukan berbagai percobaan dan mencari tahu bagaimana benda bekerja di dunia fisikaa.(Kato \& Meeteren, 2008).

Pada tahun 2015 untuk pertama kalinya Indonesia ikut survei empat tahunan menilai kemampuan matematika dan sains siswa kelas IV SD. Meninjau dari hasil penelitian Trends in International Mathematics and Science Study (TIMSS) tahun 2015, kemampuan dan daya imajinasi anak Indonesia masih lemah karena masih berada diurutan terbawah.(Nasional kompas, 2016)
Senada dengan hasil penelitian, Piasta, dan Bowles bahwa sedikit penelitian yang mengkaji secara khusus tentang pengetahuan sains di usia prasekolah terkait tentang konten-konten sains.(Guo, Piasta, \& Bowles, 2015). Peneliti juga menemukan bahwa pengenalan sains fisika di PAUD sejauh ini belum terlaksana secara optimal. Anak masih belum menunjukkan pemahaman terhadap objek atau bendabenda tak hidup seperti sifat dan perubahan zat seperti air, dan gerak yang ada di lingkungan sekitar sehingga kurangnya peduli terhadap apa yang ada di lingkungan sekitarnya. Anak belum dapat membandingkan perbedaan ciri-ciri benda yang di amati. Anak belum memahami kenapa benda dapat berpindah kekiri atau berindah kekanan. Anak belum terbiasa untuk berpikir kritis mencari jawaban sendiri atas kegiatan pemecahan masalah.

Melatih anak sejak dini untuk berfikir kritis dalam mengamati masalah, menganalisis, memecahkan masalah merupakan salah satu keterampilan sains. Kharbach berpendapat dalam penelitian Fuad, Zubaidah, Mahanal dan Suarsini "The dominant thinking skill that is strongly needed in this $21^{\text {st }}$ century is critical thinking skills" artinya keterampilan yang dibutuhkan pada abad 21 ini adalah keterampilan berpikir kritis.(Fuad, Zubaidah, Mahanal, \& Suarsini, 2017) Senada dengan pendapat Charlesworth dan Lind bahwa anak-anak tumbuh pada masa dunia teknologi sehingga mereka berinteraksi setiap hari dengan teknologi. Sangat mungkin bahwa gaya hidup dan peluang kerja dimasa depan dapat bergantung pada keterampilan yang berkaitan dengan bidang ilmu fisika atau physical science. (Rosalind Charlesworth Weber State University \& Lind, 2010) Menyadari bahwa anak-anak tumbuh pada abad 21 atau masa dunia teknologi 
20 | Pengaruh Model Pembelajaran dan Kemampuan Berpikir Kritis terhadap Pemahaman Sains Fisik

sehingga sangat penting untuk mengenalkan sains sejak dini pada anak untuk menyiapkan keterampilan dimasa depan.

Proses pembelajaran tidak pernah luput dari berbagai macam metode, teknik, strategi, media, dan model pembelajaran yang variatif sesuai dengan tujuan dan kebutuhan. Model pembelajaran merupakan salah satu penunjang keberasilan guru dalam proses pembelajaran. Salah satu model pembelajaran yang dapat diterapkan guru dalam mengajar yaitu model pembelajaran quantum. Pembelajaran quantum didasari atas keyakinan bahwa semua orang bisa belajar dengan efektif dengan interaksi yang menyenangkan, menarik, dan menantang.

Senada dengan hasil penelitian Susiani, Dantes, Tika tentang pengaruh model pembelajaran quantum terhadap kecerdasan sosio-emosional dan prestasi belajar IPA siswa kelas V di Banyuning bahwa terdapat pengaruh yang positif. Hasil penelitian ini membuktikan bahwa guru di sekolah dapat menerapkan langkahlangkah strategi Tandur (tumbuhkan, alami, namai, ulangi, dan rayakan) dalam model pembelajaran Quantum.(Ketut Susiani, Nyoman Dantes, 2013). Penelitian yang dilakukan oleh Bahaddin dan Yusuf juga membuktikan bahwa terdapat pengaruh pendekatan quantum terhadap prestasi akademik sains serta pengembangan sikap terhadap akademik sains siswa sekolah dasar.(Bahaddin \& Yusuf, 2014). Hasil penelitian terdahulu telah membuktikan bahwa terdapat pengaruh yang positif dalam mengembangkan sains anak sejak dini pada anak melalui model pembelajaran yang menarik dan menyenangkan yaitu model pembelajaran quantum.

Berdasarkan beberapa hasil penelitian yang relevan dan belum optimalnya penelitian yang mengkaji tentang kemampuan sains fisika menggunakan model pembelajaran quantum serta fakta permasalahan yang ditemukan di lapangan, sehingga perlu dilakukan penelitian tentang pengaruh model pembelajaran dan kemampuan berpikir kritis terhadap pemahaman physical science atau sains fisika.

Pemahaman merupakan kata benda dalam tahapan ranah kognitif taksonomi bloom yang lama kemudian dirivisi menjadi kata kerja yaitu memahami. Darmawan dan Sujoko dalam penelitiannya menyebutkan dalam revisi taksonomi bloom memahami berkaitan dengan aktivitas menafsirkan, memberi contoh, meringkas , menarik inferensi/ menyimpulkan, membandingkan, dan menjelaskan .(Darmawan \& Sujoko, 2013).

Sains merupakan salah satu aspek yang penting untuk dipelajari anak usia dini. Menurut Kaptan dan Korkmaz dalam penelitian Bahaddin dan Yusuf bahwa salah satu tujuan pendidikan sains juga untuk membantu anak mengakomodasikan perubahan dan perkembangan lingkungan.(Bahaddin \& Yusuf, 2014) Sains untuk anak usia dini dapat dilakukan melalui kegiatan yang menyenangkan atau bermain.

Adapun salah satu ruang lingkup sains yang dipelajari menurut "The National Science Education Standards" yaitu physical science.(National Committee on Science Education Standards and Assessment, 1996) Menurut Jackman Physical Science atau ilmu fisika physical science adalah ilmu yang mempelajari materi tak hidup. (Hilda L Jackman, Nancy H. Beaver, 2015) Sama halnya dengan ilmu biologi, manusia juga dapat mempelajari sains fisika untuk diamati dan di analisis gejala dan reaksinya. Misalnya bagaimana benda bergerak dan berpindah, bagaimana benda berubah wujud, bagaimana sifat-sifat benda, dan lainnya. Charlesworth dan Lind 
berpendapat bahwa dalam ilmu fisika diharapkan anak-anak dapat memahami sifat benda dan bahan, posisi dan gerak benda, cahaya, panas, listrik, dan magnet.(Rosalind Charlesworth Weber State University \& Lind, 2010)

Berdasarkan penjelasan di atas dapat disintesiskan bahwa pemahaman Physical Science atau sains fisika untuk anak usia dini adalah kemampuan anak memahami konsep benda-benda mati di lingkungan sehari-hari meliputi materi dan gerak yang terdiri dari ciri-ciri dan sifat benda padat, cair dan gas, perubahan benda padat, cair dan gas, dan perubahan gerak benda dengan cara menafsirkan, memberi contoh, meringkas, menarik inferensi, membandingkan, dan menjelaskan.

Menurut Santrock berfikir adalah kegiatan yang melibatkan manipulasi dan transformasi dalam memori dengan tujuan membentuk konsep, alasan, pikiran kritis dan penyelesaian masalah.(Santrock, 2007) Orang yang cerdas akan melakukan tindakan melihat dan menilai dengan baik. Namun, jika mereka tidak melakukan penjelajahan atau mencari kebenaran maka yang dilakukan adalah praktik berpikir yang buruk. Hal ini lah yang memungkinkan perlunya mengembangkan keterampilan berpikir sehingga menciptakan kemampuan berfikir yang kritis.

Warker dalam penelitian Fuad, Zubaidah, Mahanal dan Suarsini menyatakan bahwa berpikir kritis adalah proses intelektual dalam menciptakan konsep, menerapkannya, menganalisisnya, mensintesisnya, dan mengevaluasi banyak hal informasi yang didapat dari hasil pengamatan, pengalaman, dan refleksi yang dimilikinya.(Fuad et al., 2017) Seseorang yang berpikir kritis bukanlah berarti berpikir keras melainkan berpikir lebih baik mengasah keingintahuan intelektualnya dengan mengajukan pertanyaan bagaimana dan mengapa, mengumpulkan bukti-bukti kebenaran, berani berpendapat, memiliki ide-ide atau konsep baru dalam sebuah keputusan.

Menurut Deporter quantum adalah interaksi yang mengubah energi menjadi cahaya. Model pembelajaran quantum mengubah bermacam-macam interaksi yang ada di sekitar lingkungan belajar. (DeporteR, Bobbi, 2010) Lingkungan pembelajaran merupakan salah satu unsur untuk menciptakan pemercepatan belajar yaitu dengan menata lingkungan belajar seperti mewarnai, menggunakan musik, menambah hiasan dinding, dan lainya sedangkan menyediakan fasilitas adalah salah satu cara menciptakan lingkungan belajar yang menyenangkan. Acat dan Ay berpendapat bahwa model pembelajaran quantum adalah model pembelajaran yang berbeda dengan model pemebelajaran lainnya karena menggunakan musik, merayakan belajar, dan mengatur lingkungan belajar.(Bahaddin \& Yusuf, 2014)

Model pembelajaran quantum dipilih karena bersandar pada konsep "Bawalah Dunia Mereka ke Dunia Kita dan Antarkan Dunia Kita ke Dunia Mereka".(DeporteR, Bobbi, 2010) Selain itu Deporter, Reardon, dan Singer juga menyatakan bahwa model pembelajaran quantum memiliki lima prinsip yaitu segalanya berbicara, segalanya bertujuan, pengalaman sebelum pemberian nama, akui setiap usaha, dan jika layak dipelajari, maka layak pula dirayakan.(DeporteR, Bobbi, 2010) Berdasarkan kelima prinsip tersebut, maka model pembelajaran quantum hendaknya diterapkan dikelas secara ringkas dan menyajikan manfaat atau membangkitkan motivasi bagi peserta didik. Aktivitas tersebut dikenal "AMBAK" yang merupakan singkatan "Apa Manfaatnya bagiKu". Keunggulan lainnya yang dimiliki oleh model pembelajaran ini adalah 
$22 \mid$ Pengaruh Model Pembelajaran dan Kemampuan Berpikir Kritis terhadap Pemahaman Sains Fisik

kerangka pembelajaran "TANDUR" yang dikenalkan oleh DePorter yaitu Tumbuhkan, Alami, Namai, Demontrasikan, Ulangi dan Rayakan.(Deporter, 2009)

Model pembelajaran contextual teaching and learning dikembangkan oleh Elainen B.Jhonson, Ph.D pada tahun 2002. Menurut Johnson model pembelajaran contextual teaching and learning adalah sebuah sistem belajar yang didasarkan pada filosofi bahwa anak mampu menyerap pelajaran apabila mereka menangkap makna dalam materi akademis yang mereka terima, dan mereka menangkap makna dalam tugas-tugas sekolah jika mereka bisa mengaitkan informasi baru dengan pengetahuan dan pengalaman yang sudah mereka miliki sebelumnya.(Johnson, 2010) Merupakan suatu proses pendidikan yang mengkaitkan materi pembelajaran dengan konteks kehidupan anak sehari-hari (konteks pribadi, sosial, dan kultural) sehingga anak memiliki pengetahuan /keterampilan baru dan mampu menghubungkan dengan pengetahuan yang telah dimilikinnya. Model pembelajaran contextual teaching and learning berlandaskan filosofi konstruktivisme, yaitu filosofi belajar yang menekankan bahwa belajar tidak hanya sekedar menghafal. Anak harus mengkonstruksi pengetahuan di benak mereka sendiri. Anak akan belajar dengan baik jika apa yang dipelajari terkait dengan apa yang telah diketahui melalui kegiatan yang terjadi disekelilingnya.

\section{METODE PENELITIAN}

Metode yang digunakan dalam penelitian ini adalah metode eksperimen. Metode ini melihat hubungan kausal antara faktor resiko dan suatu efek tertentu melalui perlakuan yang diberikan terhadap salah satu atau lebih kelompok yang terkendali. Desain yang digunakan pada penelitian ini adalah rancangan desain treatment by level $2 \times 2$. Adapun desain penelitian ini terbagi atas tiga variabel dengan rincian variabel bebas dibentuk menjadi dua bagian yaitu variabel perlakuan menggunakan model pembelajaran quantum dan model pembelajaran contextual teaching and learning. (A), variabel bebas atribut yaitu kemampuan berfikir kritis yang terdiri dari berpikir kritis tinggi dan berfikir kritis rendah (B), sedangkan variabel terikatnya adalah pemahaman sains fisika.

\begin{tabular}{|c|c|c|}
\hline \multirow{2}{*}{} & \multicolumn{2}{|c|}{ Model Pembelajaran } \\
\cline { 2 - 3 } $\begin{array}{c}\text { Berpikir } \\
\text { Kritis (B) }\end{array}$ & $\begin{array}{c}\text { Model } \\
\text { Pembelajar } \\
\text { an } \\
\text { Quantum }\end{array}$ & $\begin{array}{c}\text { Model } \\
\text { Pembelajaran } \\
\text { Contextual } \\
\text { Teaching And } \\
\text { Learning }\end{array}$ \\
\hline $\begin{array}{c}\text { Tinggi } \\
\text { (B1) }\end{array}$ & $\mathrm{A}_{1} \mathrm{~B}_{1}$ & $\mathrm{~A}_{2} \mathrm{~B}_{1}$ \\
\hline $\begin{array}{c}\text { Rendah } \\
\text { (B2) }\end{array}$ & $\mathrm{A}_{1} \mathrm{~B}_{2}$ & $\mathrm{~A}_{2} \mathrm{~B}_{2}$ \\
\hline
\end{tabular}

Populasi pada penelitian ini adalah seluruh siswa Taman Kanak-kanak kelompok B yang berada di kenagarian Maninjau dan Tanjung Sani Kecamatan Tanjung Raya, Kabupaten Agam. Adapun teknik pengambilan sampel adalah stratified multistage cluster random sampling. Taman Kanak-kanak Islam Rasuna Said sebagai kelas eksperimen yang terdiri dari 40 siswa dengan menggunakan model pembelajaran quantum dan Taman Kanak-kanak Listrina Antokan sebagai kelas kontrol yang terdiri dari 40 siswa dengan menggunakan model pembelajaran contextual teaching and learning. Teknik pengumpulan data yang dilakukan dalam penelitian ini menggunakan dua instrumen yaitu data hasil pemahaman sains fisika menggunakan tes perbuatan dan tes lisan 
dan kemampuan berpikir kritis tinggi dan rendah. Untuk mendapatkan kelompok tinggi dan kelompok rendah dilakukan dengan menyusun urutan responden berdasarkan skor yang diperolehnya yaitu dari skor tertinggi hingga terendah mulai 25\% sampai dengan 33\%.(Swerdlik, 2009)

\section{HASIL DAN PEMBAHASAN}

Berdasarkan analisa data yang dilakukan hasil temuan penelitian antara lain:

Pertama perbedaan pemahaman sains fisika pada kelompok anak yang diajar dengan model pembelajaran quantum lebih tinggi dibandingkan dengan kelompok anak yang diajar dengan model pembelajaran contextual teaching and learning. Hasil perhitungan ANAVA di atas bahwa $\mathrm{F}_{\text {hitung }}=8.96>\mathrm{F}_{\text {tabel }}=4.02$ pada taraf signifikan $\alpha=0.05$, dengan demikian $\mathrm{H}_{0}$ ditolak dan hipotesis $\mathrm{H}_{1}$ diterima, oleh karena itu pemahaman sains fisika yang menggunakan model pembelajaran quantum $\quad \bar{X}=58.28$ lebih baik secara nyata dibandingkan yang menggunakan model pembelajaran contextual teaching and learning $\bar{X}=$ 56.28. Hal ini membuktikan bahwa secara keseluruhan hipotesis penelitian adalah pemahaman sains fisika pada kelompok anak yang diajar dengan model pembelajaran quantum lebih tinggi dibandingkan dengan kelompok anak yang diajar dengan model pembelajaran contextual teaching and learning.

Temuan dari hasil penelitian ini dapat dibuktikan peneliti melihat anak sangat antusias mengikuti game sederhana "pesan berantai" pada kegiatan awal proses pembelajaran, sehingga perasaan senang dan nyaman anak-anak saat proses pembelajaran sudah dibangun sejak awal sampai akhir pembelajaran.
Sebenarnya model pembelajaran contextual teaching and learning juga merupakan model pembelajaran yang juga berpusat pada anak, akan tetapi perbedan yang paling mendasar pada penelitian ini bahwa model pembelajaran quantum teaching memiliki interaksi-interaksi yang tercipta dari proses pembelajaran yang menyenangkan seperti penataan bangku yang berbeda-beda, musik yang mampu menciptakan suasana belajar yang menyenangkan sehingga menarik minat anak untuk mengikuti pembelajaran. Peneliti juga menemukan ada beberapa anak yang menggerakkan kepalanya ke kiri dan ke kanan mengikuti alunan musik yang diputar saat kegiatan inti sambil bersenandung. Menggunakan musik merupakan salah satu penataan lingkungan belajar yang dapat menyibukkan otak kanan ketika sedang berkonsentrasi pada aktivitas otak kiri. Yayuk berpendapat dalam penelitiannya pembelajaran yang menyenangkan dengan menggunakan alat bantu seperti penataan bangku yang berbeda-beda, musik yang mampu menciptakan suasana belajar yang menyenangkan sehingga menarik minat anak untuk mengikuti pembelajaran.(Yayuk, 2015)

Model pembelajaran ini sama-sama memiliki pengaruh terhadap pemahaman sains fisika anak, namun model pembelajaran quantum teaching menunjukkan hasil yang lebih baik dalam kegiatan pembelajaran yang dilakukan dibandingkan dengan model pembelajaran contextual teaching and learning. Peneliti menemukan seorang anak pada perlakuan hari ke 3 sangat antusias bercerita kepada guru tentang benda cair yang ada di rumahnya. Berdasarkan pembahasan hasil penelitian, maka dapat direkomendasikan model pembelajaran quantum teaching sebagai salah satu model pembelajaran 
24 | Pengaruh Model Pembelajaran dan Kemampuan Berpikir Kritis terhadap Pemahaman Sains Fisik

yang efektive digunakan untuk pemahaman sains fisika anak.

Kedua, Terdapat interaksi antara model pembelajaran dengan kemampuan berpikir kritis terhadap pemahaman sains fisika (INT A x B). Hasil dari perhitungan ANAVA diketahui bahwa pengujian hipotesis kedua disajikan dalam tabel ANAVA pada baris interaksi A $x$ B menunjukkan $\mathrm{H}_{0}$ ditolak berdasarkan nilai $\mathrm{F}_{\text {hitung }}=33.37>\mathrm{F}_{\text {tabel }}(0.05)=4.02$. Rangkuman hasil perhitungan data melalui ANAVA 2x2 dapat dilihat pada Gambar 1.1 dibawah ini :

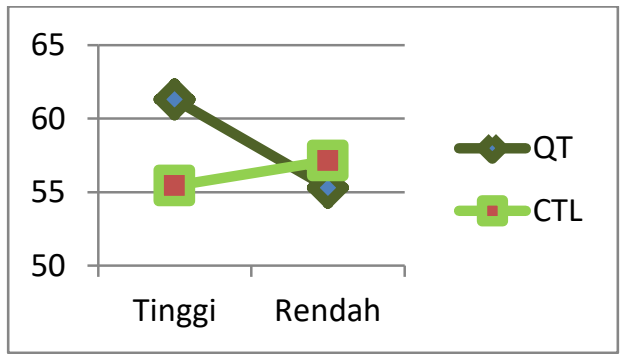

Gambar 1.1 Interaksi Bentuk Model Pembelajaran Dengan

\section{Kemampuan Berpikir Kritis Terhadap} Pemahaman Sains Fisika

Berdasarkan gambar di atas dapat dilihat bahwa nilai rata-rata skor pemahaman sains fisika pada setiap perlakuan dari model pembelajaran quantum dengan kemampuan berpikir kritis anak saling berpotongan. Hal ini membuktikan adanya interaksi antara kedua variabel, yaitu model pembelajaran dengan kemampuan berpikir kritis terhadap pemahaman sains fisika.

Peneliti melihat bahwa model pembelajaran quantum teaching dan kemampuan berpikir kritis tinggi samasama memberikan kontribusi yang besar terhadap pemahaman sains fisika anak, dimana semakin tinggi kemampuan berpikir kritis anak maka semakin tinggi pula pemahaman anak terhadap sains fisika. Hal ini disebabkan karena berpikir kritis yang ideal yaitu selalu mengajukan pertanyaan bagaimana dan mengapa atas masalah yang ditemukan, mengumpulkan bukti-bukti sebagai penguat pendapat yang diajukan, mempertimbangkan dan mengevaluasi sebuah hasil sebagai kebenaran. Sebaliknya, semakin rendah kemampuan berpikir kritis maka akan semakin sulit pula pemahaman sains pemahaman anak terhadap sains fisika.

Peneliti menemukan bahwa anak yang memiliki kemampuan berpikir kritis selalu menjawab pertanyaan yang diajukan oleh guru, selalu memberanikan diri untuk melakukan percobaan sains terlebih dahulu di depan teman-temannya. Bahkan ada anak yang mampu memahami contoh sifat air mengalir dari tempat yang tinggi ke tempat yang rendah yang di ceritakan guru tentang bencana longsor yang terjadi di sekitar kita

Hal ini menunjukkan bahwa karakteristik dan kemampuan berpikir kritis yang dimiliki setiap anak berbeda. Pentingnya pemilihan model pembelajaran yang tepat sehingga dapat menunjang semua karakteristik anak yang berbedabeda. Berdasarkan temuan yang diperoleh pada penelitian ini dapat disimpulkan bahwa terdapat interaksi antara model pembelajaran dan kemampuan berpikir krtis terhadap pemahaman sains fisika anak.

Ketiga, Perbedaan pemahaman sains fisika kelompok anak yang memiliki kemampuan berpikir kritis tinggi dan diajar dengan model pembelajaran quantum lebih tinggi dibandingkan dengan kelompok anak diajar dengan model pembelajaran contextual teaching and learning.

Perhitungan analisis varians tahap lanjut dengan menggunakan uji Tukey adalah untuk membandingkan pemahaman sains fisika kelompok anak yang memiliki kemampuan berpikir kritis tinggi yang di ajar dengan model pembelajaran quantum 
dan kelompok anak yang diajar dengan model pembelajaran contextual teaching and learning diperoleh nilai $\mathrm{Q}_{\text {hitung }}=13.02$ lebih besar daripada $\mathrm{Q}_{\text {tabel }}=4.11$ atau $\mathrm{Q}_{\text {hitung }}>\mathrm{Q}_{\text {tabel }}$ pada taraf signifikan $\alpha=$ 0.05 , dengan demikian $\mathrm{H}_{0}$ ditolak dan hipotesis alternative $\mathrm{H}_{1}$ diterima.

Selain itu skor rata-rata anak yang memiliki kemampuan berpikir kritis tinggi yang diajar dengan model pembelajaran quantum $\bar{X}=61.28$ lebih tinggi secara nyata dibandingkan anak yang di ajarkan dengan model pembelajaran contextual teaching and learning $\bar{X}=55.28$. Hal ini membuktikan bahwa pemahaman sains fisika kelompok anak yang di ajar dengan model pembelajaran quantum dan memiliki kemampuan berpikir kritis tinggi lebih tinggi dibandingkan kelompok anak yang diajar dengan model pembelajaran contextual teaching and learning dan memiliki kemampuan berpikir kritis tinggi.

Berdasarkan hasil uji hipotesis kedua model pembelajaran ini memiliki tujuan yang sama mempengaruhi pemahaman sains fisika anak, akan tetapi memiliki perbedaan dalam proses pelaksanaannya. Maksudnya disini model pembelajaran quantum dapat menciptakan ikatan emosional dengan anak seperti menjalin rasa simpati dan saling pengertian, memahami karakteristik anak, mengetahui minat dan bakat mereka, serta berbagi pengalaman. Guru memberikan keteladanan bagi anak seperti berbicara jujur, menjadi pendengar yang baik dan selalu gembira atau murah tersenyum. Selain itu guru harus pandai memahami perasan dan sikap anak-anak dengan cara mengajak bermain game sederhana, aktivitas kelompok untuk menambah kekompakan dan juga bisa menambahkan musik klasik ketika proses pembelajaran berlansung.
Hasil temuan lainnya menggunakan model pembelajaran quantum teaching mempengaruhi suasana belajar yaitu ketika di kelas anak belajar dengan bergairah dan sangat sedikit tampak anak yang cemas dan bosan. Saat berbagi cerita pengalaman di rumahnya anak-anak selalu rebutan untuk memberitahu apa yang pernah dialami dan diketahuinya. Bahkan ada salah satu anak yang memiliki kemampuan berpikir kritis tinggi saat mengamati guru mencontohkan percobaan sains dia selalu mengomentari apa yang terjadi seolah-olah mengetahui, mengerti dan memahaminya serta meyakinkan teman-temannya bahwa yang di sebutkan itu benar dengan sangat percaya diri. Walaupun kegiatan percobaan sains ini selalu diulang-ulang pada hari itu tetapi anak tidak pernah menunjukkan rasa bosan untuk melakukannya lagi.

Menutup kegiatan pembelajaran guru selalu memberikan pujian dan mengajak anak bernyanyi bersama untuk merayakan keaktifan anak-anak dalam kegiatan pembelajaran hari ini, setelah itu anak selalu bertanya kepada guru besok kegitan apa yang akan mereka lakukan, seolah-olah mereka tidak sabar untuk kembali ke sekolah. Berdasarkan hal tersebut dapat disimpulkan bahwa pemahaman sains fisika anak yang memiliki kemampuan berpikir kritis tinggi sebaiknya diajar dengan model pembelajaran quantum teaching.

Keempat, Perbedaan pemahaman sains fisika kelompok anak yang memiliki kemampuan berpikir kritis rendah dan diajar dengan model pembelajaran quantum lebih tinggi dibandingkan dengan kelompok anak diajar dengan model pembelajaran contextual teaching and learning.

Perhitungan analisis varians tahap lanjut dengan menggunakan uji Tukey adalah untuk membandingkan pemahaman sains fisika kelompok anak yang memiliki kemampuan berpikir kritis rendah yang di 
26 | Pengaruh Model Pembelajaran dan Kemampuan Berpikir Kritis terhadap Pemahaman Sains Fisik

ajar dengan model pembelajaran quantum dan kelompok anak yang diajar dengan model pembelajaran contextual teaching and learning diperoleh nilai $\mathrm{Q}_{\text {hitung }}=-4.13$ lebih kecil daripada $\mathrm{Q}_{\text {tabel }}=4.11$ atau $\mathrm{Q}_{\text {hitung }}$ $>\mathrm{Q}_{\text {tabel }}$ pada taraf signifikan $\alpha=0.05$, dengan demikian $\mathrm{H}_{0}$ ditolak dan hipotesis alternative $\mathrm{H}_{1}$ diterima.

Oleh karena itu, kelompok anak yang memiliki kemampuan berpikir kritis rendah yang diajarkan dengan pembelajaran quantum $\bar{X}=55.42$ lebih rendah secara nyata dibandingkan kelompok anak yang diajar dengan model pembelajaran contextual teaching and learning $\bar{X}=$ 57.14 . Hal ini membuktikan bahwa hipotesis penelitian kelompok anak yang memiliki kemampuan berpikir kritis rendah yang di ajar dengan model pembelajaran contextual teaching and learning lebih tinggi dibandingkan dengan kelompok anak yang diajar dengan model pembelajaran quantum.

Secara alamiah anak memiliki perkembangan yang berbeda-beda baik perkembangan kognitif, afektif, psikomotor, kematangan emosi, kepribadian, dan sosial meosionalnya. Akan tetapi setiap anak memiliki kemampuan yang tak terbatas dalam belajar tergantung stimulisasi dan usaha yang dilakukan orang tua, lingkungan maupun guru disekolah.

Begitu pula halnya kemampuan berpikir kritis merupakan ciri-ciri memiliki keingintahuan yang tinggi terhadap lingkungan sekitarnya. Seseorang yang memiliki kemampuan berpikir kritis akan menanyakan bagaimana dan mengapa itu terjadi, bukan hanya menanyakan apa yang terjadi, mencari bukti-bukti yang mendukung "fakta" dan mengajukan pertanyaan-pertanyaan dan berani berspekulasi untuk menciptakan ide-ide dan informasi-informasi baru. (Santrock, 2007)
Biasanya anak yang memiliki keingintahuan yang tinggi selalu mengajukan pertanyaan bagaimana dan mengapa atas masalah yang ditemukan serta mengumpulkan bukti-bukti yang dia temukan dalam menjawab keingintahuannya.

Berdasarkan hasil pengolahan data dan perhitungan data yang dilakukan bahwa terdapat perbedan pemahaman sains fisika anak yang diajar dengan model pembelajaran quantum teaching yang memiliki kemampuan berpikir kritis rendah dengan kelompok anak yang diajar dengan model pembelajaran contextual teaching and learning yang memiliki kemampuan berpikir kritis rendah. Hasil yang didapat menunjukkan bahwa pemahaman sains fisika anak yang diajar dengan model pembelajaran quantum teaching yang memiliki kemampuan berpikir kritis rendah lebih rendah dibandingkan dengan kelompok anak yang diajar dengan model pembelajaran contextual teaching and learning yang memiliki kemampuan berpikir kritis rendah.

Anak usia dini sebenarnya sudah menunjukkan kemampuan berpikir kritis melalui rasa ingintahu yang tinggi ketika suka bertanya, mengamati sesutu hal yang baru, mengeksplorasi lingkungan sekitarnya. Setiap anak memiliki kemampuan berpikir kritis yang berbedabeda tergantung stimulasi orang tua serta interaksi dengan lingkungan sekitarnya. Saat anak menunjukkan kebiasaan kurang peka terhadap hal baru yang ada di lingkungan sekitarnya, tidak tertarik untuk mengajukan pertanyaan apa dan mengapa atau mengungkapkan isi pikirannya maka ini merupakan salah satu ciri-ciri anak yang memiliki kemampuan berpikir kritis yang rendah. Hal ini sejalan dengan pendapat Ennis dalam penelitian Nilson, Fetherston, McMurray menggambarkan karakteristik pemikir kritis yang ideal yaitu seorang 
pemikir kritis yang ideal dalam menentukan apa yang harus dipercaya dan apa yang harus dilakukan selalu bersifat terbuka dan berusaha untuk menjadi baik dan lebih baik, menilai suatu sumber dengan cara mengidentifikasi kebenaran melalui pertanyaan, memiliki bukti dan asumsi yang tepat dan mempertahankannya. merumuskan praduga yang masuk akal serta menarik kesimpulan secara hati-hati saat memutuskan apa yang harus dipercaya dan apa yang harus dilakukan. Artinya bahwa ciri-ciri orang yang memiliki kemampuan berpikir kritis yang ideal yaitu selalu mengajukan pertanyaan bagaimana dan mengapa atas masalah yang ditemukan, mengumpulkan bukti-bukti sebagai penguat pendapat yang diajukan, mempertimbangkan dan mengevaluasi sebuah hasil sebagai kebenaran, dan berani berspekulasi untuk menciptakan ide-ide dan informasiinformasi baru.

Pada penelitian ini peneliti menemukan bahwa kelompok anak berpikir kritis rendah ketika diajar dengan model pembelajaran quantum teaching ada 3 orang anak yang tidak mau ikut aktif dalam kegiatan, mereka hanya sekedar mengikuti langkah-langkah kegitan tanpa menunjukkan ekpresi gembira dan keingintahuan untuk bertanya. Ketika teman-temannya rebutuan untuk menceritakan benda-benda apa saja yang ada dirumahnya, mereka hanya melihat dan mendengarkan saja. Saat guru mengajukan pertanyaan kepada salah satu si anak dia hanya terdiam malu dan menjawabnya dengan suara yang lembut.

Dapat disimpulkan pada penelitian ini bahwa anak yang memiliki kemampuan berpikir kritis rendah jika di ajar dengan menggunakan model pembelajaran quantum teaching yang menekankan keterlibatan aktif anak atau berpusat pada anak sejak awal kegiatan sampai akhir akan kurang berpengaruh terhadap mereka. Karena memiliki rasa ketertarikan yang sedikit dan keberminatan terhadap kegiatan yang dilakukan. Pemahaman sains fisika anak akan lebih baik jika disertai dengan kemampuan berpikir kritis tinggi.

Hasil temuan yang sangat mengejutkan sebaliknya bahwa ternyata anak yang memiliki kemampuan berpikir kritis rendah diajar dengan model pembelajran contextual teaching and learning tidak menjadi penghalang untuk menunjukkan hasil yang lebih baik. Karena salah satu kelebihan contextual teaching and learning menghadirkan dunia nyata pada anak sehingga anak bekerja, mengalami, mengkonstruk sendiri pengetahuannya dan mendorong anak untuk membuat hubungan dengan pengetahuan yang dimilikinya. Hal ini sejalan dengan yang dilakukan peneliti mengajak anak bermain percobaan sains fisika di lingkungan terbuka dengan memberikan kebebasan kepada anak untuk mengeksplorasi sendiri lingkungannya. Hal ini peneliti buktikan sendiri dari hasil pengamatan selama penelitian berlansung, ada beberapa anak yang selalu diam saat masuk kelas sampai selesai kegiatan. Ketika guru bercerita dan berdiskusi dan saling tanya jawab dia hanya mendengarkan saja, ketika guru mengajaknya bicara dia diam saja. Anak tidak menunjukkan sikap yang antusias saat mengikuti pelajaran sepeti teman lainnya. Selain itu peneliti juga merasakan hal yang aneh karena orang tua si anak selalu menemaninya di sekolah bahkan juga masuk ke dalam kelas.

Hal yang mengejutkan itu terjadi pada pertemuan ke-3 saat kegiatan percobaan sains mulai dilakukan di luar sekolah yaitu kegiatan membuat gelembung udara menggunakan daun kembang sepatu dan deterjen peneliti melihat si anak tersenyum dan bercerita dengan temannya 
28 | Pengaruh Model Pembelajaran dan Kemampuan Berpikir Kritis terhadap Pemahaman Sains Fisik

saat meniup balon. $\mathrm{Si}$ anak mulai berinteraksi dengan teman-temannya bahkan mulai ikut menceritakan bagaimana perasaannya hari ini dan kegiatan apa yang dilakukan hari ini. Sampai pertemuan terakhir terlihat sekali ada perubahan yang terjadi pada anak yaitu ia sudah mulai antusias untuk melakukan kegiatan dan ikut menjawab pertanyaan guru walupun dengan suara yang lembut.

Memiliki kemampuan berpikir kritis rendah tidak menjadi penghalang untuk meningkatkan keterlibatan anak dalam proses pembelajaran akan tetapi dibutuhkan model pembelajaran yang sesuai dan tepat untuk diterapkan. Sama halnya model pembelajaran quantum teaching dan model pembelajaran contextual teaching and learning sama-sama memiliki keunggulan dan kelemahannya masing-masing.

\section{KESIMPULAN}

Berdasarkan hasil analisis data, hasil pengujian hipotesis dan hasil pembahasan penelitian yang telah diperoleh maka dapat dismpulkan bahwa: pertama, pemahaman sains fisika anak yang diajar dengan model pembelajaran quantum memiliki pengaruh yang lebih tinggi daripada anak yang diajar dengan model pembelajaran contextual teaching and learning; kedua ,terdapat pengaruh interaksi antara model pembelajaran dan kemampuan berpikir kritis terhadap pemahaman sains fisika anak sesuai dengan tinggi rendahnya kemampuan berpikir kritis anak; ketiga, pemahaman sains fisika anak yang memiliki kemampuan berpikir kritis tinggi yang di ajar dengan model pembelajaran quantum memiliki skor yang lebih tinggi daripada anak yang diajar dengan model pembelajaran contextual teaching and learning; empat, pemahaman sains fisika yang memiliki kemampuan berpikir kritis rendah yang di ajar dengan model pembelajaran quantum memiliki skor yang lebih rendah daripada anak yang diajar dengan model pembelajaran contextual teaching and learning.

\section{UCAPAN TERIMA KASIH}

Penulis mengucapkan terima kasih kepada reviewer, monev penelitian dan teman sejawat yang telah memberikan saran perbaikan artikel ini. Terkhusus kepada rekan yang membantu pengumpulan data

\section{DAFTAR PUSTAKA}

Bahaddin, M., \& Yusuf. (2014). An investigation the effect of quantum learning approach on primary school 7th grade students, science achievement, retention and attitude. Educational Research Association The International Journal of Research in Teacher Education, 5(2), $11-23$.

Darmawan, I. P. A., \& Sujoko, E. (2013). Revisi Taksonomi Pembelajaran Benyamin S. Bloom. Satya Widya, 29(1), 30.https://doi.org/10.24246/j.sw.201 3.v29.i1.p30-39

DeporteR, Bobbi, M. R. \& S. S. N. (2010). Quantum Teaching: Mempraktikkan Quantum Learning Di Ruang-Ruang Kelas. Bandung: Kaifa.

Deporter, B. A. M. H. (2009). Quantum Learning: Membiasakan Belajar Nyaman Dan Menyenangkan. (Alwiyah Abdurrahman, Ed.). Bandung: Kaifa.

Fuad, N. M., Zubaidah, S., Mahanal, S., \& Suarsini, E. (2017). Improving Junior High Schools' Critical Thinking Skills Based on Test Three Different Models of Learning. International Journal of Instruction, 10(1), 101-116. https://doi.org/10.12973/iji.2017.101 
$7 \mathrm{a}$

Guo, Y., Piasta, S. B., \& Bowles, R. P. (2015). Exploring Preschool Children's Science Content Knowledge. Early Education and Development, 26(1), 125-146. https://doi.org/10.1080/10409289.20 15.968240

Hilda L Jackman, Nancy H. Beaver, S. S. W. (2015). Early Education Curriculum: A Child's Connection to The World (Sixth).

Johnson, E. B. P. . (2010). Contextual Teaching Ang Learning : Menjadikan Kegiatan Belajar-Mengajar Mengasyikkan dan Bermakna. (I. Setiawan, Ed.). California: Ka.

Kato, T., \& Meeteren, B. D. Van. (2008). Physical Science in Constructivist Early Childhood Classrooms. Childhood Education, 84(4), 234. https://doi.org/10.1080/00094056.20 08.10523015

Ketut Susiani, Nyoman Dantes, I. N. (2013). Kecerdasan Sosio-Emosional Dan Prestasi Belajar Ipa Siswa Kelas V Sd Di Banyuning Program Studi Pendidikan Dasar , Program Pascasarjana Universitas Pendidikan Ganesha Singaraja , Indonesia eJournal Program Pascasarjana Universitas Pendidikan Ganesha, 3(3).

National Committee on Science Education Standards and Assessment, N. R. council. (1996). National Science Education Standards National. Potentials. Washington,Dc: N Ational Academy Press.https://doi.org/10.1016/j.jmgm. 2005.11.005

Olcer, S. (2017). Science Content Knowledge of 5-6 Year Old Preschool Children. International Journal of Environmental and Science Education, 12(2), 143-175. Retrieved from http://ezproxy.lib.uconn.edu/login?ur l=https://search.ebscohost.com/login. aspx direct $=$ true $\& \mathrm{db}=$ eric $\& \mathrm{AN}=\mathrm{EJ} 1$ $137395 \&$ site $=$ ehost-live

Rosalind Charlesworth Weber State University, E., \& Lind, K. K. (2010). Math and science for young children. (C. S. Development, Ed.) (SIXTH EDIT). America.

Santrock, J. W. (2007). Perkembangan Anak, 11 h Edition. Jakarta: erlangga.

Swerdlik, C. (2009). Psychology: Psychological Testing And Assessment: An Introducation To Test And Measurement 7th Edition. United State Of America: The McGraw-Hill Companies, Inc.

Yayuk, S. E. (2015). Pengaruh Model Quantum Teaching Terhadap Pemahaman Konsep Ipa Dan Keterampilan Berpikir Kreatif Siswa Smp. Jurnal Penelitian Ilmu Pendidikan, 8(1), 95-111. 